\title{
Antioxidant properties and polyphenolic content in terrestrial cyanobacteria
}

\author{
Dhananjaya P. Singh ${ }^{1} \cdot$ Ratna Prabha $^{1,2} \cdot$ Shaloo Verma $^{1} \cdot$ Kamlesh K. Meena $^{3} \cdot$ \\ Mahesh Yandigeri $^{4}$
}

Received: 28 November 2016/ Accepted: 23 March 2017/Published online: 8 June 2017

(C) Springer-Verlag Berlin Heidelberg 2017

\begin{abstract}
Cell-free extracts of twenty terrestrial cyanobacteria were evaluated for their antioxidant properties in terms of free-radical scavenging (DPPH and ABTS) and metal chelating activity and deoxyribose protection. Extract of Anabaena constricta was the most prominent antioxidant agent $\left(\mathrm{IC}_{50}\right.$ for DPPH activity $0.91 \mathrm{mg} \mathrm{ml}^{-1}$, ABTS $0.23 \mathrm{mg} \mathrm{ml}^{-1}$, deoxyribose protection $0.63 \mathrm{mg} \mathrm{ml}^{-1}$ and $\mathrm{Fe}^{+2}$-ion chelating $0.9 \mathrm{mg} \mathrm{ml}^{-1}$ ). The extracts of cyanobacterial species contained high quantity of total phenol and total flavonoid that were supposed to impart prominent antioxidant properties. Cyanobacterial species also showed fairly high PAL activity. We reported varied quantities of polyphenolics gallic, chlorogenic, caffeic, vanillic and ferulic acids and flavonoids rutin, quercetin and kaempferol in cyanobacterial extracts. The presence of these polyphenolics was linked with the free radical scavenging, metal chelating and antioxidative damage protecting properties of the organisms. Cyanobacteria are the most feasible, promising and alternative candidates for searching out new chemical leads for industrial applications in pharmaceuticals, neutraceuticals and biomolecules of importance. Presence of
\end{abstract}

Dhananjaya P. Singh

nabg.nbaim@gmail.com

1 ICAR-National Bureau of Agriculturally Important Microorganisms, Kushmaur, Maunath Bhanjan 275103, India

2 Chhattisgarh Swami Vivekanand Technical University (CSVTU), Bhilai, Chhattisgarh, India

3 ICAR-National Institute of Abiotic Stress Management, School of Edaphic Stress Management, Malegaon (Kh.), Baramati 413115, India

4 ICAR-National Bureau of Agricultural Insect Resources (NBAIR), Hebbal, Bangalore, Karnataka 560024, India biomolecules such as polyphenolics and their connection with the prominent biological functions (e.g., antioxidant properties) make these organisms a potential source of secondary metabolites with predominant biological activities. Additionally, dominant presence of polyphenols as antioxidant agents in cyanobacterial species may reflect their adaptation strategies against abiotic stresses for their ecological success in different habitats.

Keywords Cyanobacteria - Flavonoids - Antioxidants · HPLC · Gallic acid · Polyphenolics

\section{Introduction}

Cyanobacteria are promising prokaryotic photosynthetic microorganisms that act as potential cell factories producing a wide array of secondary metabolites of different class and groups including venturamide $A$, dragomabin, dragonamide -A, -B, carmabin -A, -B, calothrixins -A, -B, dolastatins and nostocarboline (Rastogi and Sinha 2009a, b; Guedes et al. 2013; Xue and He 2015). Additionally, these organisms have the capabilities to express plant P450 proteins that have essential functions in the biosynthesis of natural product molecules (Xue and $\mathrm{He}$ 2015). Chemically diverse group of secondary metabolites of biotechnological and industrial significance (Rastogi and Sinha 2009a, b; Mandal and Rath 2015) potentiate cyanobacteria with promising biological activities (antibacterial, antialgal, antiviral, anticancer, immuno-suppressant, anti-inflammatory, antioxidant and biotoxins) (Singh et al. 2001; Aydas et al. 2013). Such compounds also impart intrinsic self-defense mechanisms to the cells that directly interact with the diverse environmental conditions (Camacho 2008). Many species exhibit wide range 
of chemical diversity with characteristic structures coupled with bioactivity that make these organisms a potential candidate for pharmaceuticals (Mandal and Rath 2015). Cyanobacterial species also exhibit potential adaptation strategies against oxidative stresses mainly by the activation of antioxidant defense system that comprises activation of various enzymes (superoxide dismutase, catalase, glutathione reductase and ascorbate peroxidase) (Bharanidharan et al. 2013; Guedes et al. 2013).

Phenylpropanoids and their derivatives are probably the largest group of secondary metabolites isolated from natural sources (plants, microorganisms and microalgal cultures) (Wojdylo et al. 2007; Vogt 2010). They are potential antioxidants that scavenge reactive oxygen species (ROS) (Perron and Brumaghim 2009). The detoxification of ROS by means of enzymatic and/or non-enzymatic antioxidants like phenylpropanoids protects cell damage and minimizes the loss due to oxidative responses (Reuter et al. 2010). Since these organisms are among the most primitive prokaryotes having faced several extreme environmental stresses during their evolution (Tomitani et al. 2006), it is imperative to understand that their capabilities to produce antioxidative enzymes and secondary metabolites might have offered them protective strategies against abiotic stresses.

Plant phenolics and flavonoids are the known antioxidants that reduce the oxidative damage inside the cells (Nordberg and Arnér 2001; Singh et al. 2009; Fraga et al. 2010). Because of the presence of unique phenylpropanoids, cyanobacteria could be a new source of these secondary metabolites (Xue and He 2015). We evaluated antioxidant property of the extracts of terrestrial cyanobacterial species from the genera Anabaena, Nostoc, Microcheate, Oscillatoria, Synechocystis, Hapalosiphon, Mastigocladus, Scytonema, Westiellopsis, Cylindrospermum, Aulosira, Chroococcus, Lyngbya, Calothrix, Dichothrix, Limnothrix and Phormidium. Targeted metabolomics using qualitative and quantitative determination of polyphenolics (phenolic acids and flavonoids) was performed in these species using High Performance Liquid Chromatography (HPLC) followed by liquid chromatography-mass spectrometry (LC-MS) to identify and quantify the compounds of interest.

\section{Materials and methods}

\section{Reagents, organisms and culture conditions}

Twenty different cyanobacterial species were obtained from National Agriculturally Important Microbial Culture Collection (NAIMCC) at ICAR-NBAIM, Maunath Bhanjan, India. These species were Anabaena doliolum
(NAIMCC-1), Calothrix geitonos (NAIMCC-4), Dichothrix sp. (NAIMCC-7), Limnothrix obliqueacuminata (NAIMCC-8), Microcheate tenera (NAIMCC-12), Oscillatoria acuta (NAIMCC-17), Nostoc ellipsosporum (NAIMCC-28), Anabaena constricta (NAIMCC-29), Synechocystis sp. (NAIMCC-33), Hapalosiphon fontinalis (NAIMCC-36), Mastigocladus laminosus (NAIMCC-43), Scytonema simplex (NAIMCC-45), Calothrix brevissima (NAIMCC-48), Westiellopsis prolifica (NAIMCC-51), Cylindrospermum sp. (NAIMCC-70), Aulosira fertilissima (NAIMCC-94), Chroococcus sp. (NAIMCC-100), Limnothrix sp. (NAIMCC-107), Lyngbya sp. (NAIMCC-111), and Phormidium tenue (NAIMCC-113). Organisms were grown and maintained in BG11 medium (Stanier et al. $1971)$ in flasks $(100 \mathrm{ml} \times 6)$ at $25 \pm 1{ }^{\circ} \mathrm{C}$ with light/dark cycle of $12 \mathrm{~h}$ till exponentially growing phase is attained. Culture flasks were bubbled with air containing $1 \%(\mathrm{v} / \mathrm{v})$ carbon dioxide and were kept under continuous illumination at $70 \mu \mathrm{Em}^{-2} \mathrm{~s}^{-2}$ from incandescent lamps. Exponentially growing cultures were harvested by centrifugation at $5000 \mathrm{~g}$ at room temperature and cell pellets were finally used for extraction using appropriate solvents.

\section{Biochemical assays}

Chlorophyll and total carotenoid content in cyanobacterial cultures was quantified by extracting pigments from exponentially growing cyanobacterial cultures $(0.5 \mathrm{~g}$ fresh wt, moisture content $15 \pm 2 \%$ ) in $80 \%$ acetone for $3-4 \mathrm{~h}$ at room temperature. After removal of the cell debris through centrifugation at $15,000 \mathrm{~g}$ for $10 \mathrm{~min}$, chlorophyll and carotenoids in the supernatant were quantified in terms of $\mathrm{A}_{665}$ and $\mathrm{A}_{450}$, respectively (Ferjani et al. 2003).

Total protein content was extracted and quantified as per the method described by Ferjani et al. 2003. Freshly harvested one gm cultures (moisture content $15 \pm 2 \%$ ) was macerated with $1 \%$ tricholoroacetic acid $(5 \mathrm{ml})$ with intermittent sonication in cold conditions and the suspension was centrifuged (Sigma D-37520) at $15,000 \mathrm{~g}$ for $10 \mathrm{~min}$ at $4{ }^{\circ} \mathrm{C}$. The cell pellet was suspended in $1 \mathrm{~N}$ $\mathrm{NaOH}$ (4 ml), boiled for $30 \mathrm{~min}$, cooled and again centrifuged at $15,000 \mathrm{~g}$ for $5 \mathrm{~min}$. The supernatant was quantified for total protein content by Lowry method (Lowry et al. 1951) taking bovine serum albumin (BSA) as standard.

\section{Preparation of cell-free extracts}

Two gm of fresh cyanobacterial culture was extracted with $10 \mathrm{ml}$ of methanol for $4 \mathrm{~h}$ followed by re-extraction with $10 \mathrm{ml}$ of water:methanol $(1: 1, \mathrm{v} / \mathrm{v})$ for $3 \mathrm{~h}$. Intermittent sonication for 4-5 min was given. The process was 
repeated thrice and the supernatant was pooled together and centrifuged at $10,000 \mathrm{~g}$ for $15 \mathrm{~min}$. Clear greenish supernatant was collected and lyophilized to obtain cellfree extracts. Dried extract was then dissolved in $2 \mathrm{ml}$ of HPLC grade methanol by vortexing and was stored at $4{ }^{\circ} \mathrm{C}$ for further analysis.

\section{Antioxidant assays}

\section{DPPH activity}

Free radical scavenging activity (FRSA) was determined using 2, 2-diphenyl-1-picrylhydrazyl (DPPH) solution $\left(0.6 \mu \mathrm{M} \mathrm{l}^{-1}\right.$ in ethanol) (Yen and Duh 1994) and was expressed as antiradical power (ARP). Briefly, $1 \mathrm{ml}$ of methanolic cyanobacterial extract was mixed with $4 \mathrm{ml}$ of DPPH solution and reaction mixture was kept in dark for $30 \mathrm{~min}$. Discoloration in the reaction mixture was monitored at initial $(0 \mathrm{~min})$ and after $30 \mathrm{~min}$ at $517 \mathrm{~nm}$ taking methanol as blank. The results were recorded as \% discoloration.

\section{ABTS activity}

The assay was based on the ability of antioxidant compounds/extracts to scavenge $2,2^{\prime}$-azino-bis(ethylbenzthiazoline-6-sulfonic acid (ABTS ${ }^{+}$) radical cation (Giao et al. 2007). The radical cation was prepared by mixing $7 \mathrm{mM}$ ABTS solution with potassium persulfate $(1 / 1 ; \mathrm{v} / \mathrm{v})$ while leaving the reaction mixture for $6 \mathrm{~h}$. Scavenging activity of cell free extracts of cyanobacteria was evaluated in a reaction mixture containing $0.9 \mathrm{ml}$ of $\mathrm{ABTS}^{+}$free radical and $0.1 \mathrm{ml}$ of cyanobacterial methanolic extracts. The absorbance of the reaction mixture was recorded at $734 \mathrm{~nm}$ after $15 \mathrm{~min}$ and expressed as \% ABTS activity.

\section{Deoxyribose protection assay}

The efficacy of methanolic extract of cyanobacteria on prevention of $\mathrm{Fe}^{2+} / \mathrm{H}_{2} \mathrm{O}_{2}$-induced decomposition of deoxyribose was determined (Halliwell and Gutteridge, 1984). In brief, a reaction mixture contains $450 \mu \mathrm{l}$ of $0.2 \mathrm{M}$ phosphate buffer $(\mathrm{pH}=0.7), 150 \mu 1$ of $10 \mathrm{mM}$ deoxyribose, $150 \mu \mathrm{l}$ of $10 \mathrm{mM} \mathrm{FeSO}, 150 \mu \mathrm{l}$ of $10 \mathrm{mM}$ EDTA, $500 \mu \mathrm{l}$ of distilled water and $100 \mu \mathrm{l}$ of methanolic extracts. The reaction was started by the addition of $150 \mu \mathrm{l}$ of $10 \mathrm{mM} \mathrm{H} \mathrm{H}_{2} \mathrm{O}_{2}$ and after incubation at $37{ }^{\circ} \mathrm{C}$, reaction was stopped by adding $750 \mu \mathrm{l}$ of $2.8 \%$ TCA and $750 \mu \mathrm{l}$ of $1 \%$ TBA in $50 \mathrm{mM} \mathrm{NaOH}$. The absorbance was recorded at $532 \mathrm{~nm}$ in spectrophotometer (Thermo UV10) taking ascorbic acid as reference.
$\mathrm{Fe}^{+2}$-ion chelating activity

The ferrous $\left(\mathrm{Fe}^{+2}\right)$-ion chelating activity of methanolic extracts of cyanobacteria was determined (Dinis et al. 1994). Methanolic extracts $(0.5 \mathrm{ml})$ were mixed with $100 \mu \mathrm{l}$ of $2 \mathrm{mM}$ ferrous chloride solution and the reaction was initiated by adding $200 \mu \mathrm{l}$ of $5 \mathrm{mM}$ ferrozine. The mixture was shaken vigorously and incubated at room temperature for $10 \mathrm{~min}$. The absorbance of the solution was measured at $562 \mathrm{~nm}$. The percentage of inhibition of ferrozine- $\mathrm{Fe}^{+2}$ complex formation was calculated using the following formula.

Ferrous ion chelating ability $(\%)=\left[\left(A_{0}-\mathrm{A}\right) /\right.$ $\left.A_{0}\right] \times 100$ where, $A_{0}$ is the absorbance of the control solution (containing all reagents except the extract); $A$ is absorbance in the presence of the extract sample. The experiment was carried out in triplicate and ethylenediaminetetraacetate (EDTA) was used as standard.

\section{Enzyme assays}

Enzyme extract of all the twenty cyanobacterial strains was prepared by extracting $1 \mathrm{~g}$ fresh culture (moisture content $15 \pm 2 \%$ ) with $3 \mathrm{ml}$ of $0.05 \mathrm{M}$ phosphate buffer ( $\mathrm{pH} 7.8$ ) containing $1 \mathrm{mM}$ EDTA and $2 \%(\mathrm{w} / \mathrm{v})$ polyvinylpyrolidone. The suspension was sonicated and the supernatant from the homogenate was obtained by centrifugation at $13,000 \mathrm{~g}$ for $15 \mathrm{~min}$ at $4{ }^{\circ} \mathrm{C}$. The supernatant was used for the estimation of phenylalanineammonialyase (PAL) activity.

\section{PAL activity}

PAL (EC 4.3.1.24) activity in enzyme extracts of cyanobacterial strains was determined as per the method reported by McCallum and Walker (1990). The assay mixture consisted of $500 \mu \mathrm{l}$ of phosphate buffer $(100 \mathrm{mM}$, pH 7.0), $200 \mu \mathrm{l}$ enzyme extract and $1.3 \mathrm{ml}$ distilled water. The reaction was initiated by the addition of $1 \mathrm{ml} \mathrm{L}-$ phenylalanine $(100 \mathrm{mM})$. Tubes were incubated at $30^{\circ} \mathrm{C}$ for $30 \mathrm{~min}$ (or one $\mathrm{h}$ when the activity was low) and the reaction was stopped by the addition of $500 \mu \mathrm{l}$ of $1 \mathrm{M}$ trichloroacetic acid (TCA). Tubes were then centrifuged for $5 \mathrm{~min}$ at $5000 \mathrm{~g}$ and the absorbance was recorded at $\mathrm{A}_{290}$. Cinnamic acid was used as standard to calculate PAL activity. Triplicate assays were performed for each cyanobacterial strain.

\section{Estimation of total phenolics and flavonoids}

Total phenolic content (TPC) in the cyanobacterial strains was assessed using Folin-Ciocalteu's reagent (Machu et al. 2015). Gallic acid was used as standard compound and 
total phenol content was expressed in terms of mg gallic acid equivalents (GAE) $\mathrm{g}^{-1}$ fresh wt.

Total flavonoid content was measured by aluminum chloride colorimetric method (Kim et al. 2003). Cyanobacterial extract $(0.5 \mathrm{ml})$ was mixed with $0.1 \mathrm{ml}$ of $10 \%$ aluminum chloride hexahydrate, potassium acetate $(0.1 \mathrm{ml}$ of $1 \mathrm{M})$ and $2.8 \mathrm{ml}$ of deionized water. After incubation for $30 \mathrm{~min}$, the absorbance of the reaction mixture was recorded at $415 \mathrm{~nm}$ and quantified taking quercetin as standard. Total flavonoid content (TFC) was expressed in terms of $\mu \mathrm{g}$ quercetin equivalents (QE) $\mathrm{g}^{-1}$ fresh cell wt.

\section{HPLC analysis of extracts}

Estimation of polyphenolics (phenolic acids and flavonoids) in the cyanobacterial cell-free extracts was performed using HPLC system (515, Waters, USA) equipped with binary Waters 515 reciprocating pumps, a variable photodiode array (PDA) detector (Waters 2996) and system controller empowered with Empower ${ }^{\mathrm{TM}}$ software for data acquisition, integration and analysis. Reverse phase liquid chromatographic separation of the phenolic extracts was carried out at room temperature with the following conditions; injection volume $10 \mu \mathrm{l} / \mathrm{sample}$, separation mode- isocratic, column C-18 $(250 \times 4.6 \mathrm{~mm}$ i.d., particle size $5 \mu \mathrm{m})$, mobile phasemethanol:0.4\% acetic acid in water $(55: 45 \%$, v/v), flow rate$1 \mathrm{ml} / \mathrm{min}$ and detection at 254 and $280 \mathrm{~nm}$ (Singh et al. 2011). Phenolic acids (gallic, chlorogenic, caffeic, vanillic and ferulic acids) and flavonoids (rutin, quercetin, and kaempferol) (Sigma-Aldrich) were used as standard compounds. Samples were subjected to membrane filtration $(0.45 \mu \mathrm{m})$ prior to injection in the HPLC column. Characterization of the compounds in the sample was done by comparing retention time with the standard compounds and by co-injection while quantification was done by comparing peak areas of identified compounds in the samples with those of the standard compounds.

\section{Qualitative LC-MS}

Phenolic constituents were used as standards. Their presence in each cyanobacterial strains was validated by mass spectrometric analysis (Singh et al. 2009). Compounds were detected by their respective $\mathrm{m} / \mathrm{z}$ values of parent and product ions.

\section{Results and discussion}

Plants have always remained potential source of phenylpropanoids and other natural chemicals. Biosynthetic mechanisms for the synthesis of phenolic acids, flavonoids, flavones and their derivatives have been well established (Vogt 2010). Microalgae, especially cyanobacteria being non-conventional and less explored source of phenylpropanoids, pose immense scope for searching out unique secondary metabolites with potential bioactivities because of the ease of mass-scale cultivation in limited time frame, small space and low cost. Various other qualities of cyanobacteria like oxygenic photosynthesis, ability to survive in extreme habitats and amenability to genetic engineering make them prominent platform as cell factories for the targeted biosynthesis of secondary metabolites (Xue and He 2015).

We evaluated twenty strains of cyanobacteria belonging to different genera including Anabaena, Nostoc, Microcheate, Oscillatoria, Synechocystis, Hapalosiphon, Mastigocladus, Scytonema, Westiellopsis, Cylindrospermum, Aulosira, Chroococcus, Lyngbya, Calothrix, Dichothrix, Limnothrix and Phormidium that were isolated from different habitats. Growth of these organisms was recorded in terms of chlorophyll, carotenoids and protein content at the time of harvesting in their exponential phase (Table 1). There has been marked variation in the content of total chlorophyll, protein and carotenoids of cyanobacterial strains. Maximum content of chlorophyll $\left(3.35 \mathrm{mg} \mathrm{g}^{-1}\right.$ fresh wt), total protein $\left(7.62 \mathrm{mg} \mathrm{g}^{-1}\right.$ fresh $\left.\mathrm{wt}\right)$ and total carotenoid (605.67 $\mathrm{mg} \mathrm{g}^{-1}$ fresh wt) was found in Lyngbya sp. while minimum content of chlorophyll $\left(0.53 \mathrm{mg} \mathrm{g}^{-1}\right.$ fresh wt) was recorded in $H$. fontinalis, total protein (1.32 $\mathrm{mg} \mathrm{g}^{-1}$ fresh wt) in L. obliqueacuminata and total carotenoids $\left(77.73 \mu \mathrm{g} \mathrm{g}^{-1}\right.$ fresh wt) in S. simplex.

Since we determined antioxidant properties and polyphenolics content of cyanobacterial extracts, it was pertinent to assess the activity of PAL enzyme which catalyzes the initial reaction of phenylpropanoid biosynthesis in plants (Hanson and Havir 1981). The activity of PAL is known to undergo dramatic changes in the cells under the conditions of biotic and abiotic stresses (Ronald and Soderhall 1985; Aydas et al. 2013). PAL activity leading to the production of cinnamic acid may further lead to the biosynthesis of a number of polyphenolics within the cells. We reported maximum PAL activity in $O$. acuta $(21.6 \mu \mathrm{g}$ cinnamic acid $\mathrm{g}^{-1}$ fresh wt $\mathrm{h}^{-1}$ ) followed by Lyngbya sp. (16.8 $\mu \mathrm{g}$ cinnamic acid $\mathrm{g}^{-1}$ fresh $\mathrm{wt}^{-1}$ and M. laminosus (11.7 $\mu \mathrm{g}$ cinnamic acid $\mathrm{g}^{-1}$ fresh $\mathrm{wt} \mathrm{h}^{-1}$ ) (Fig. 1). Minimum PAL activity $\left(1.08 \mu \mathrm{g}\right.$ cinnamic acid $\mathrm{g}^{-1}$ fresh $\mathrm{wt} \mathrm{h}^{-1}$ ) was recorded in $L$. obliqueacuminata. After PAL estimation, total phenol content (TPC) and total flavonoid content (TFC) was determined in the cyanobacterial extracts (Table 2). High quantity of TPC (290.23, 107.07 and $92.03 \mathrm{mg} \mathrm{GAE} \mathrm{g}^{-1}$ fresh wt in O. acuta, M. laminosus and Lyngbya sp., respectively) and TFC (634.0, 370.47 and $275.47 \mu \mathrm{g} \mathrm{QE} \mathrm{g}^{-1}$ fresh wt in O. acuta, M. laminosus and Synechocystis sp., respectively) was recorded (Table 2). 
Table 1 Source of organisms and total content of chlorophyll, carotenoids and protein in cyanobacteria

\begin{tabular}{|c|c|c|c|c|}
\hline Organisms $^{\mathrm{a}}$ & Accession and Origin & $\begin{array}{l}{ }^{\mathrm{A}} \text { Chlorophyll content } \\
\left(\mathrm{mg} \mathrm{g}^{-1} \text { fresh w) }\right.\end{array}$ & $\begin{array}{l}{ }^{\mathrm{B}} \text { Total protein content } \\
\left(\mathrm{mg} \mathrm{g}^{-1} \text { fresh } \mathrm{w}\right)\end{array}$ & $\begin{array}{l}{ }^{\mathrm{C}_{\text {Total }}} \text { carotenoid } \\
\left(\mu \mathrm{g} \mathrm{g}^{-1} \text { fresh } \mathrm{w}\right)\end{array}$ \\
\hline Anabaena doliolum & NAIMCC-1; Porompat, Manipur & $2.14 \pm 0.07^{\mathrm{b}}$ & $5.57 \pm 0.11^{\mathrm{d}}$ & $356.60 \pm 9.4^{\mathrm{f}}$ \\
\hline Calothrix geitonos & NAIMCC-4; Singda, Manipur & $0.70 \pm 0.07^{\mathrm{f}-\mathrm{i}}$ & $1.74 \pm 0.07^{\mathrm{k}}$ & $178.47 \pm 7.9^{\mathrm{j}}$ \\
\hline Dichothrix sp. & NAIMCC-7; Ukhrul, Manipur & $0.71 \pm 0.07^{\mathrm{fgh}}$ & $1.64 \pm 0.08^{\mathrm{k}}$ & $102.9 \pm 5.6^{\mathrm{n}}$ \\
\hline Limnothrix obliqueacuminata & NAIMCC-8; Wangkhei, Manipur & $0.75 \pm 0.08^{\mathrm{fg}}$ & $1.32 \pm 0.03^{1}$ & $155.60 \pm 11.7^{\mathrm{k}}$ \\
\hline Microcheate tenera & NAIMCC-12; Kumbi, Manipur & $0.67 \pm 0.06^{\mathrm{f}-\mathrm{i}}$ & $2.19 \pm 0.09^{\mathrm{i}}$ & $146.80 \pm 5.3^{\mathrm{kl}}$ \\
\hline Oscillatoria acuta & NAIMCC-17; Tamu, Burma & $1.69 \pm 0.16^{\mathrm{c}}$ & $7.53 \pm 0.087^{\mathrm{a}}$ & $526.70 \pm 8.8^{\mathrm{b}}$ \\
\hline Nostoc ellipsosporum & NAIMCC-28; Varanasi, U.P. & $0.77 \pm 0.06^{\mathrm{fg}}$ & $3.17 \pm 0.075^{\mathrm{g}}$ & $243.97 \pm 8.5^{\mathrm{h}}$ \\
\hline Anabaena constricta & NAIMCC-29; Varanasi, U.P. & $1.01 \pm 0.14^{\mathrm{e}}$ & $3.27 \pm 0.095^{\mathrm{g}}$ & $361.60 \pm 5.3^{\mathrm{f}}$ \\
\hline Synechocystis sp. & NAIMCC-33; Jodhpur, Rajasthan & $1.99 \pm 0.12^{\mathrm{b}}$ & $6.21 \pm 0.11^{\mathrm{b}}$ & $508.17 \pm 4.7^{\mathrm{c}}$ \\
\hline Hapalosiphon fontinalis & NAIMCC-36; Nagpur, Maharastra & $0.53 \pm 0.06^{\mathrm{i}}$ & $1.96 \pm 0.09^{\mathrm{j}}$ & $94.43 \pm 1.8^{\mathrm{n}}$ \\
\hline Mastigocladus laminosus & NAIMCC-43; Nagpur, Maharastra & $1.82 \pm 0.11^{\mathrm{c}}$ & $5.83 \pm 0.08^{c}$ & $480.40 \pm 7.3^{\mathrm{d}}$ \\
\hline Scytonema simplex & NAIMCC-45; Baharaich, U.P. & $0.68 \pm 0.05^{\mathrm{f}-\mathrm{i}}$ & $1.66 \pm 0.07^{\mathrm{k}}$ & $77.73 \pm 5.9^{\circ}$ \\
\hline Calothrix brevissima & NAIMCC-48; Baharaich, U.P. & $0.84 \pm 0.09^{\mathrm{f}}$ & $3.53 \pm 0.09^{\mathrm{f}}$ & $206.43 \pm 4.9^{\mathrm{i}}$ \\
\hline Westiellopsis prolifica & NAIMCC-51; Baharaich, U.P. & $1.36 \pm 0.08^{\mathrm{d}}$ & $5.57 \pm 0.14^{\mathrm{d}}$ & $449.53 \pm 9.4^{\mathrm{e}}$ \\
\hline Cylindrospermum sp. & NAIMCC-70; South, Goa & $1.03 \pm 0.1^{\mathrm{e}}$ & $4.40 \pm 0.17^{\mathrm{e}}$ & $237.2 \pm 6.1^{\mathrm{h}}$ \\
\hline Aulosira fertilissima & NAIMCC-94; Tamil Nadu & $0.68 \pm 0.08^{\mathrm{f}-\mathrm{i}}$ & $2.68 \pm 0.19^{\mathrm{h}}$ & $130.0 \pm 3.6^{\mathrm{m}}$ \\
\hline Chroococcus sp. & NAIMCC-100; IARI, New Delhi & $0.56 \pm 0.07^{\mathrm{hi}}$ & $3.60 \pm 0.17^{\mathrm{f}}$ & $154.5 \pm 5.2^{\mathrm{k}}$ \\
\hline Limnothrix sp. & NAIMCC-107; Takyelpat, Manipur & $1.12 \pm 0.06^{\mathrm{e}}$ & $3.55 \pm 0.18^{\mathrm{f}}$ & $268.5 \pm 8.9^{\mathrm{g}}$ \\
\hline Lyngbya sp. & NAIMCC-111; Takyelpat, Manipur & $3.35 \pm 0.12^{\mathrm{a}}$ & $7.62 \pm 0.11^{\mathrm{a}}$ & $605.67 \pm 10.7^{\mathrm{a}}$ \\
\hline Phormidium tenue & NAIMCC-113; West Agartala, Tripura & $0.60^{\mathrm{g}} \pm 0.07^{\mathrm{hi}}$ & $2.64 \pm 0.09^{\mathrm{h}}$ & $137.03 \pm 5.4^{1 \mathrm{~m}}$ \\
\hline $\mathrm{SEM} \pm$ & & 0.05 & 0.07 & 4.01 \\
\hline $\mathrm{CD}(p<0.05)$ & & 0.15 & 0.190 & 11.46 \\
\hline $\mathrm{CV}(\%)$ & & 7.9 & 3 & 2.6 \\
\hline
\end{tabular}

a Obtained from ICAR-National Bureau of Agriculturally Important Microorganisms (ICAR-NBAIM), Mau, India Culture Collection (NAIMCC)

Values represent average \pm standard deviation for three replications; values in the same column with different superscripts are significantly different at $p<0.05$

Other organisms also possess high quantity of TPC and TFC. High content of TPC in three strains namely $O$. acuta, M. laminosus and Lyngbya sp. is linked with the high activity of PAL enzyme in these organisms. Such observations reflect that a high PAL activity can result in increased biosynthesis of polyphenolics in the cells and due to this, high accumulation of total phenolics and total flavonoids was observed in these organisms.

Antioxidant activity of biological samples and/or natural compounds was evaluated by various methods. Two free radicals commonly used to evaluate antiradical and antioxidant power of biological extracts or natural compounds in vitro are 2, 2-diphenyl-1-picrylhydrazyl (DPPH) and 2, 2-azinobis (3-ethylbenzothiazoline- 6-sulfonic acid) (ABTS). Free radical scavenging activity of the cyanobacterial extracts was evaluated against three important radicals, DPPH, $\mathrm{ABTS}^{+}$and OH. DPPH method was widely used to determine antiradical and/or antioxidant power of biological extracts and/or purified compounds. It is relatively stable free radical that, upon reduction by an antioxidant loses its absorption $(515 \mathrm{~nm})$. Concentration-dependent assays for the determination of free radical scavenging activity using DPPH resulted in two categories of cyanobacterial strains, first with high activity while second with low activity. Extracts of $A$. doliolum, C. geitonos, Dichothrix sp., A. constricta, Synechocystis sp., $H$. fontanalis, M. laminosus, S. symplex, $C$. brevissima, Cylindrospermum sp., A. fertilissima and Chroococcus sp. exhibited high free radical scavenging activity in terms of DPPH activity in which more than $80 \%$ DPPH activity was recorded at the concentration of $5 \mathrm{mg} \mathrm{ml}^{-1}$ (Fig. 2a). Among cyanobacteria exhibiting low DPPH activity were $L$. obliqueaccuminata, $M$. tenera, $O$. acuta, $N$. ellipsoporum, W. prolifica, Lyngbya sp. and $P$. tenue in which less than $70 \%$ activity was achieved at $5 \mathrm{mg} \mathrm{ml}^{-1}$ and even at higher concentrations, the activity remained similar. Maximum DPPH activity $\left(\mathrm{IC}_{50}\right.$ $0.91 \mathrm{mg} \mathrm{ml}^{-1}$ cell-free extract) was recorded in A. constricta while minimum activity $\left(\mathrm{IC}_{50} 4.28 \mathrm{mg} \mathrm{ml}^{-1}\right.$ cell- 
Fig. 1 Phenylalanine ammonia lyase activity of cyanobacterial cultures

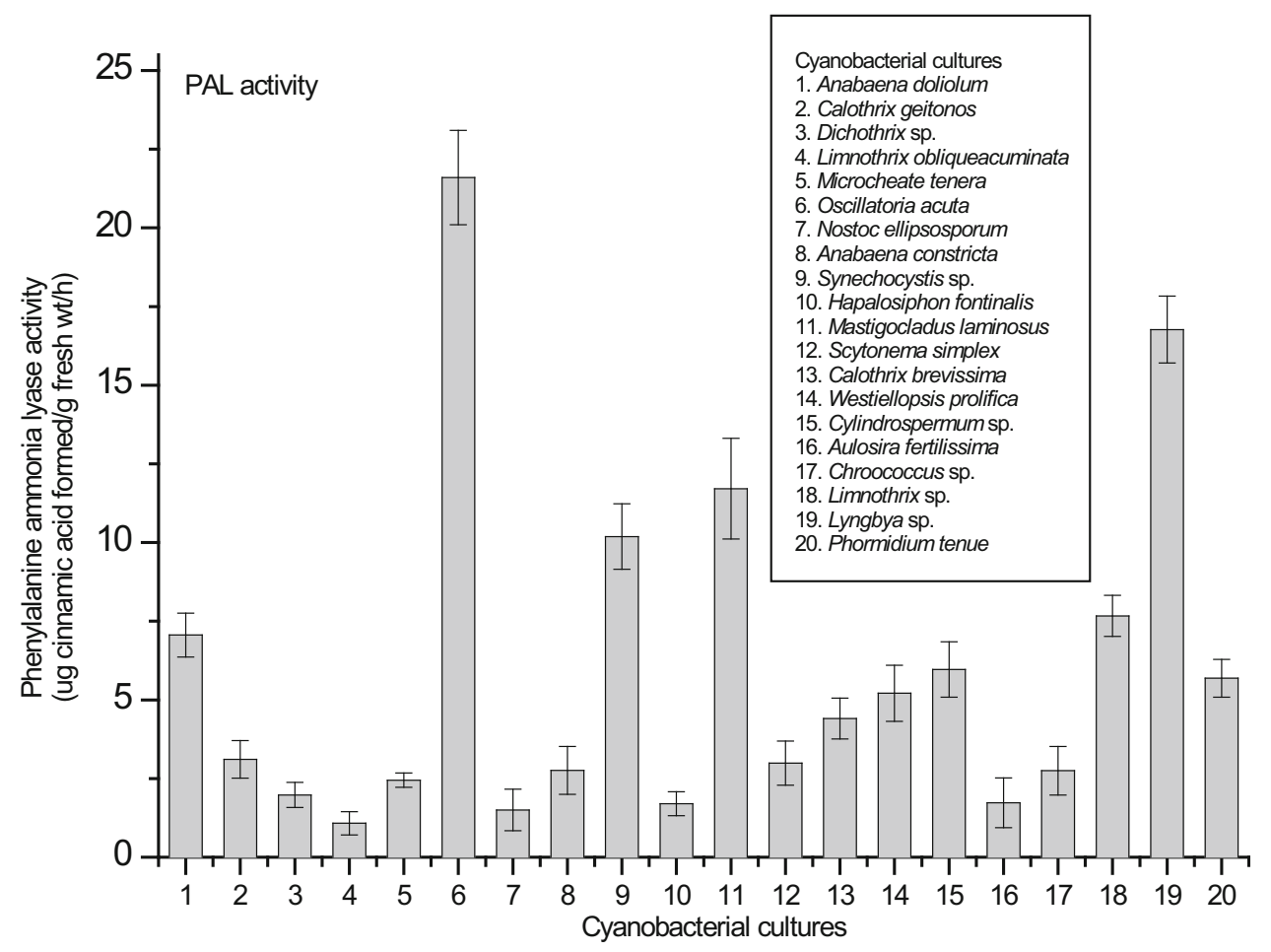

free extract) was found in M. tenera (Table 2). Similarly, high ABTS activity (above $90 \%$ at $1 \mathrm{mg} \mathrm{m}^{-1}$ ) was observed in A. doliolum, Dichothrix sp., L. obliqueaccuminata, M. tenera, N. ellipsosporum, A. constricta, Synechocystis sp., H. fontanalis, M. laminosus, C. brevissima, Cylindrospermum sp., Chroococcus sp. and P. tenue and low activity group included $C$. geitonos, O. acuta, $S$. simplex, W. prolifica, A. fertilissima, Limnothrix sp., and Lyngbya sp. (Fig. 2b).

ABTS activity of the cyanobacterial extracts ranged from $0.23 \mathrm{mg} \mathrm{ml}^{-1}\left(\mathrm{IC}_{50}\right)$ in $A$. constricta to $0.97 \mathrm{mg} \mathrm{ml}^{-1}\left(\mathrm{IC}_{50}\right)$ in O. acuta. ABTS assay determines relative ability of the extract or compound (antioxidant) to scavenge ABTS which is generated by reacting strong oxidizing agent such as potassium persulfate. Reduced blue-green ABTS radical by hydrogen-donating antioxidant in solution reflects antiradical power of the antioxidant extract or compounds. While comparing the results on DPPH and ABTS free radical scavenging activity of the extracts, it is evident that in contrast to DPPH method, ABTS method was more effective and precise. It has been shown that most phenolic antioxidants react slowly with DPPH, reaching a steady state in longer time (Bondet et al. 1997). The method also has limitations with the interference of the presence of anthocyanins that could lead to underestimation of the antioxidant activity of biological extract (Shalaby and Shanab 2013). The requirement of high concentrations of polyphenolics-rich cyanobacterial extracts for obtaining $\mathrm{IC}_{50}$ value of antioxidant activity using DPPH in comparison to ABTS may be explained on the basis of slow reaction of phenolics with DPPH.

Hydroxyl radical $\mathrm{OH}$. is an extremely reactive free radical capable of reacting with various molecules like sugars, amino acids, lipids and nucleotides in the cells (Yasuda et al. 2000). Incubation of deoxyribose with $\mathrm{H}_{2} \mathrm{O}_{2}$ and $\mathrm{Fe}^{+2}$-EDTA as chelating agent reduces degradation of deoxyribose by the addition of scavenger of $\mathrm{OH}$ - radical. The process depends on the concentration of scavenger relative to deoxyribose (Gutteridge 1984). Extracts of the plants such as Moringa oleifera (Chumark et al. 2008) and Allium cepa (Singh et al. 2009) rich in polyphenolics have shown excellent antioxidant properties and were proven good scavengers of reactive species such as $\mathrm{OH}, \mathrm{O}_{2}$ and ROO. We evaluated different concentration of cyanobacterial extracts rich in polyphenols to assess shielding effect against the degenerative reaction against deoxyribose caused by the $\mathrm{OH}$. radical in the reaction mixture. Prominent deoxyribose protection activity was shown from $0.32 \mathrm{mg} \mathrm{ml}^{-1}$ cell free extract $\left(\mathrm{IC}_{50}\right)$ in Chroococcus sp. to $7.95 \mathrm{mg} \mathrm{ml}^{-1}\left(\mathrm{IC}_{50}\right)$ in L. obliqueacuminata (Table 2). Extracts of M. tenera, A. constricta, Synechocystis sp., M. laminosus, S. simplex, C. brevissima, W. prolifica, Cylindrospermum sp., A. fertilissima, Chroococcus sp., Limnothrix sp., Lyngbya sp. and $P$. tenue showed high level (>90\% activity at $6 \mathrm{mg} \mathrm{ml}^{-1}$ cell-free extract) of $\mathrm{OH}$ radical scavenging activity and extracts of $A$. doliolum, $C$. geitonos, Dichothrix sp., L. obliqueacuminata, O. acuta, $N$. ellipsosporum and $H$. fontinalis showed low deoxyribose 
Table 2 Total phenol and flavonoids content and antioxidant potential of cyanobacterial cell-free extracts in terms of DPPH, ABTS, Deoxyribose protection and $\mathrm{Fe}^{+2}$-ion chelating activity

\begin{tabular}{|c|c|c|c|c|c|c|}
\hline \multirow[t]{2}{*}{ Organisms } & \multicolumn{2}{|l|}{ Phenolics content } & \multicolumn{4}{|c|}{ Antioxidant power $\left(\mathrm{IC}_{50}\right)\left(\mathrm{mg} \mathrm{ml}^{-1}\right.$ cell-free extract $)$} \\
\hline & $\begin{array}{l}\text { Total phenol content } \\
\left(\mathrm{mg} \text { GAE g }{ }^{-1} \text { fresh w) }\right.\end{array}$ & $\begin{array}{l}\text { Total flavonoid content } \\
\left(\mu \mathrm{g} \text { QE } \mathrm{g}^{-1} \text { fresh } \mathrm{w}\right)\end{array}$ & $\begin{array}{l}\text { DPPH } \\
\text { activity }\end{array}$ & ABTS activity & $\begin{array}{l}\text { Deoxyribose } \\
\text { protection } \\
\text { activity }\end{array}$ & $\begin{array}{l}\mathrm{Fe}^{+2} \text {-ion } \\
\text { chelation } \\
\text { activity }\end{array}$ \\
\hline Anabaena doliolum & $47.77 \pm 3.4^{\mathrm{fg}}$ & $106.93 \pm 4.25^{\mathrm{j}}$ & $2.64 \pm 0.19^{\mathrm{b}}$ & $0.39 \pm 0.04^{\text {efg }}$ & $5.26 \pm 0.11^{\mathrm{b}}$ & $1.7 \pm 0.36^{\mathrm{gh}}$ \\
\hline Calothrix geitonos & $22.80 \pm 2.3^{\mathrm{j}}$ & $91.0 \pm 1.8^{\mathrm{kl}}$ & $1.06 \pm 0.18^{\mathrm{b}}$ & $0.52 \pm 0.06^{\mathrm{cd}}$ & $3.94 \pm 0.05^{\mathrm{c}}$ & $3.5 \pm 0.4^{\mathrm{e}}$ \\
\hline Dichothrix sp. & $35.23 \pm 3.3^{\text {hi }}$ & $53.37 \pm 3.81^{\circ}$ & $1.72 \pm 0.24^{\mathrm{b}}$ & $0.47 \pm 0.06^{\text {cde }}$ & $2.96 \pm 0.09^{\mathrm{e}}$ & $3.2 \pm 0.35^{\mathrm{e}}$ \\
\hline Limnothrix obliqueacuminata & $44.80 \pm 3.9^{\mathrm{g}}$ & $106.9 \pm 7.3^{\mathrm{j}}$ & $2.95 \pm 0.2^{\mathrm{b}}$ & $0.45 \pm 0.07^{\mathrm{def}}$ & $7.95 \pm 0.09^{\mathrm{a}}$ & $3.7 \pm 0.45^{\mathrm{e}}$ \\
\hline Microcheate tenera & $45.57 \pm 5.9^{\mathrm{g}}$ & $88.37 \pm 3.8^{1}$ & $4.28 \pm 0.5^{\mathrm{b}}$ & $0.37 \pm 0.05^{\mathrm{efg}}$ & $1.84 \pm 0.08^{\mathrm{h}}$ & $8.7 \pm 0.36^{\mathrm{a}}$ \\
\hline Oscillatoria acuta & $290.23 \pm 2.2^{\mathrm{a}}$ & $634.0 \pm 5.1^{\mathrm{a}}$ & $2.63 \pm 0.36^{\mathrm{b}}$ & $0.97 \pm 0.09^{\mathrm{a}}$ & $3.64 \pm 0.05^{\mathrm{d}}$ & $1.4 \pm 0.2^{\mathrm{hi}}$ \\
\hline Nostoc ellipsosporum & $39.03 \pm 1.8^{\mathrm{h}}$ & $115.03 \pm 5.2^{\mathrm{i}}$ & $8.91 \pm 0.73^{\mathrm{a}}$ & $0.45 \pm 0.07^{\mathrm{def}}$ & $2.59 \pm 0.07^{\mathrm{f}}$ & $4.7 \pm 0.8^{\mathrm{d}}$ \\
\hline Anabaena constricta & $59.37 \pm 4.0^{\mathrm{d}}$ & $201.97 \pm 3.3^{\mathrm{d}}$ & $0.91 \pm 0.04^{\mathrm{b}}$ & $0.23 \pm 0.07^{\mathrm{h}}$ & $0.63 \pm 0.04^{\mathrm{n}}$ & $0.9 \pm 0.22^{\mathrm{i}}$ \\
\hline Synechocystis sp. & $54.93 \pm 2.65^{\mathrm{de}}$ & $275.47 \pm 2.8^{\mathrm{c}}$ & $1.52 \pm 0.06^{\mathrm{b}}$ & $0.38 \pm 0.08^{\text {efg }}$ & $0.86 \pm 0.05^{1 \mathrm{~m}}$ & $1.3 \pm 0.2^{\mathrm{hi}}$ \\
\hline Hapalosiphon fontinalis & $33.43 \pm 3.65^{\mathrm{hi}}$ & $79.43 \pm 2.9^{\mathrm{m}}$ & $3.0 \pm 0.19^{\mathrm{b}}$ & $0.44 \pm 0.04^{\mathrm{d}-\mathrm{g}}$ & $2.44 \pm 0.12^{\mathrm{g}}$ & $2.46 \pm 0.36^{\mathrm{f}}$ \\
\hline Mastigocladus laminosus & $107.07 \pm 4.04^{\mathrm{b}}$ & $370.47 \pm 2.7^{\mathrm{b}}$ & $1.67 \pm 0.11^{\mathrm{b}}$ & $0.32 \pm 0.04^{\mathrm{gh}}$ & $1.35 \pm 0.06^{\mathrm{j}}$ & $2.42 \pm 0.45^{\mathrm{fgh}}$ \\
\hline Scytonema simplex & $32.77 \pm 2.65^{\mathrm{i}}$ & $71.1 \pm 2.8^{\mathrm{n}}$ & $1.42 \pm 0.19^{\mathrm{b}}$ & $0.68 \pm 0.09^{\mathrm{b}}$ & $0.75 \pm 0.13^{\mathrm{mn}}$ & $4.5 \pm 0.38^{\mathrm{d}}$ \\
\hline Calothrix brevissima & $31.47 \pm 2.01^{\mathrm{i}}$ & $95.13 \pm 2.7^{\mathrm{k}}$ & $2.24 \pm 0.18^{\mathrm{b}}$ & $0.34 \pm 0.07^{\mathrm{fgh}}$ & $0.92 \pm 0.05^{1}$ & $2.4 \pm 0.45^{\mathrm{fg}}$ \\
\hline Westiellopsis prolifica & $58.07 \pm 4.51^{\mathrm{d}}$ & $199.2 \pm 3.13^{\mathrm{d}}$ & $3.52 \pm 0.26^{\mathrm{b}}$ & $0.67 \pm 0.04^{\mathrm{b}}$ & $0.66 \pm 0.05^{\mathrm{n}}$ & $3.8 \pm 0.8^{\mathrm{e}}$ \\
\hline Cylindrospermum sp. & $34.07 \pm 4.27^{\mathrm{hi}}$ & $157.9 \pm 2.8^{\mathrm{g}}$ & $1.27 \pm 0.06^{\mathrm{b}}$ & $0.32 \pm 0.03^{\mathrm{gh}}$ & $0.44 \pm 0.08^{\circ}$ & $1.3 \pm 0.26^{\mathrm{hi}}$ \\
\hline Aulosira fertilissima & $22.17 \pm 1.81^{\mathrm{j}}$ & $82.27 \pm 2.05^{\mathrm{m}}$ & $2.27 \pm 0.19^{\mathrm{b}}$ & $0.58 \pm 0.04^{\mathrm{bc}}$ & $1.78 \pm 0.11^{\mathrm{h}}$ & $7.8 \pm 0.45^{\mathrm{b}}$ \\
\hline Chroococcus sp. & $52.07 \pm 1.32^{\mathrm{ef}}$ & $166.67 \pm 1.96^{\mathrm{f}}$ & $1.56 \pm 0.09^{\mathrm{b}}$ & $0.32 \pm 0.06^{\mathrm{gh}}$ & $0.32 \pm 0.04^{\mathrm{o}}$ & $2.4 \pm 0.28^{\mathrm{fg}}$ \\
\hline Limnothrix sp. & $24.93 \pm 2.4^{\mathrm{j}}$ & $130.77 \pm 1.7^{\mathrm{h}}$ & $1.82 \pm 0.09^{\mathrm{b}}$ & $0.57 \pm 0.05^{\mathrm{bc}}$ & $0.81 \pm 0.04^{1 \mathrm{~m}}$ & $4.6 \pm 0.49^{\mathrm{d}}$ \\
\hline Lyngbya sp. & $92.03 \pm 1.59^{c}$ & $192.37 \pm 2.0^{\mathrm{e}}$ & $2.61 \pm 0.13^{\mathrm{b}}$ & $0.53 \pm 0.07^{\mathrm{cd}}$ & $1.15 \pm 0.05^{\mathrm{k}}$ & $2.6 \pm 0.43^{\mathrm{c}}$ \\
\hline Phormidium tenue & $30.63 \pm 1.04^{\mathrm{i}}$ & $95.20 \pm 2.05^{\mathrm{k}}$ & $2.69 \pm 0.21^{\mathrm{b}}$ & $0.33 \pm 0.05^{\mathrm{fgh}}$ & $1.54 \pm 0.05^{\mathrm{i}}$ & $1.5 \pm 0.31^{\mathrm{hi}}$ \\
\hline $\mathrm{SEM} \pm$ & 1.895 & 2.035 & 1.449 & 0.036 & 0.044 & 0.24 \\
\hline $\mathrm{CD}(p<0.05)$ & 5.415 & 5.817 & 4.142 & 0.104 & 0.126 & 0.70 \\
\hline $\mathrm{CV}(\%)$ & 5.7 & 2.1 & 99 & 13.5 & 3.6 & 12.60 \\
\hline
\end{tabular}

Values represent average \pm standard deviation for three replications; values in the same column with different superscripts are significantly different at $p<0.05$

$N D$ Not Detected, $G A E$ gallic acid equivalents, $Q E$ Quercetin equivalents

protection $\left(<75 \%\right.$ activity at $8 \mathrm{mg} \mathrm{ml}^{-1}$ cell free extract) (Fig. 2c).

Iron $\left(\mathrm{Fe}^{+2}\right)$ chelation power of cyanobacterial extracts was analysed. Methanolic extract of cyanobacteria exhibited significant capacity to chelate ferrous ions. These ions are among the most effective pro-oxidants and their reaction with $\mathrm{H}_{2} \mathrm{O}_{2}$ in the biological system leads to the formation of $\mathrm{OH}$ radicals. In the experiments, ferrozine quantitatively forms stable $\mathrm{Fe}^{+2}$-complex, the intensity of which was decreased in the presence of a chelating agent due to the interference with $\mathrm{Fe}^{+2}$-ferozine complex. The measurement of chelating activity therefore, reflects the ability of the chelating agent or the antioxidant to disrupt $\mathrm{Fe}^{+2}$-complex formation. All cyanobacterial extracts interfered with the $\mathrm{Fe}^{+2}$-complex formation in various capacities. Prominent $\mathrm{Fe}^{+2}$ chelating activity was recorded in the extracts of A. constricta, Synechocystis sp., Cylindrospermum sp., O. acuta, $P$. tenue and A. doliolum $\left(\mathrm{IC}_{50}\right.$
$0.9,1.3,1.3,1.4,1.5$ and $1.7 \mathrm{mg} \mathrm{ml}^{-1}$ cell-free extract) (Table 2). $\mathrm{Fe}^{+2}$-ion chelating activity was found to be concentration-dependent and increased with the increasing concentration of cell free extracts. Evaluation of chelating activity showed that in the extracts of six strains namely $A$. constricta, Synechocystis sp., Cylindrospermum sp., $O$. acuta $_{s} P$. tenue and A. doliolum, $>90 \%$ activity was attained at the extract concentration of $<2.5 \mathrm{mg} \mathrm{ml}^{-1}$ (Fig. 2D(a)). However, cyanobacteria with low $\mathrm{Fe}^{+2}$-ion chelating activity showed a maximum of $70-80 \%$ activity at the extract concentration of $8-10 \mathrm{mg} \mathrm{ml}^{-1}$ (Fig. 2D(b)). Excess of metal ions can lead to various anomalies in the cellular system. The iron (II) chelating activity of cyanobacterial extracts is of great significance and the transition metal ions contribute to the oxidative damage. Such activities of cyanobacterial cellular constituents might be thought to become protective to these organisms under the conditions of habitat stresses. 
Fig. 2 Concentrationdependent antioxidant activity (\%) of cyanobacterial strains a DPPH activity, b ABTS activity, c Deoxyribose protection activity and $\mathbf{d} \mathrm{Fe}^{+2}$ ion chelating activity; Extracts with high (a) and low (b) activity
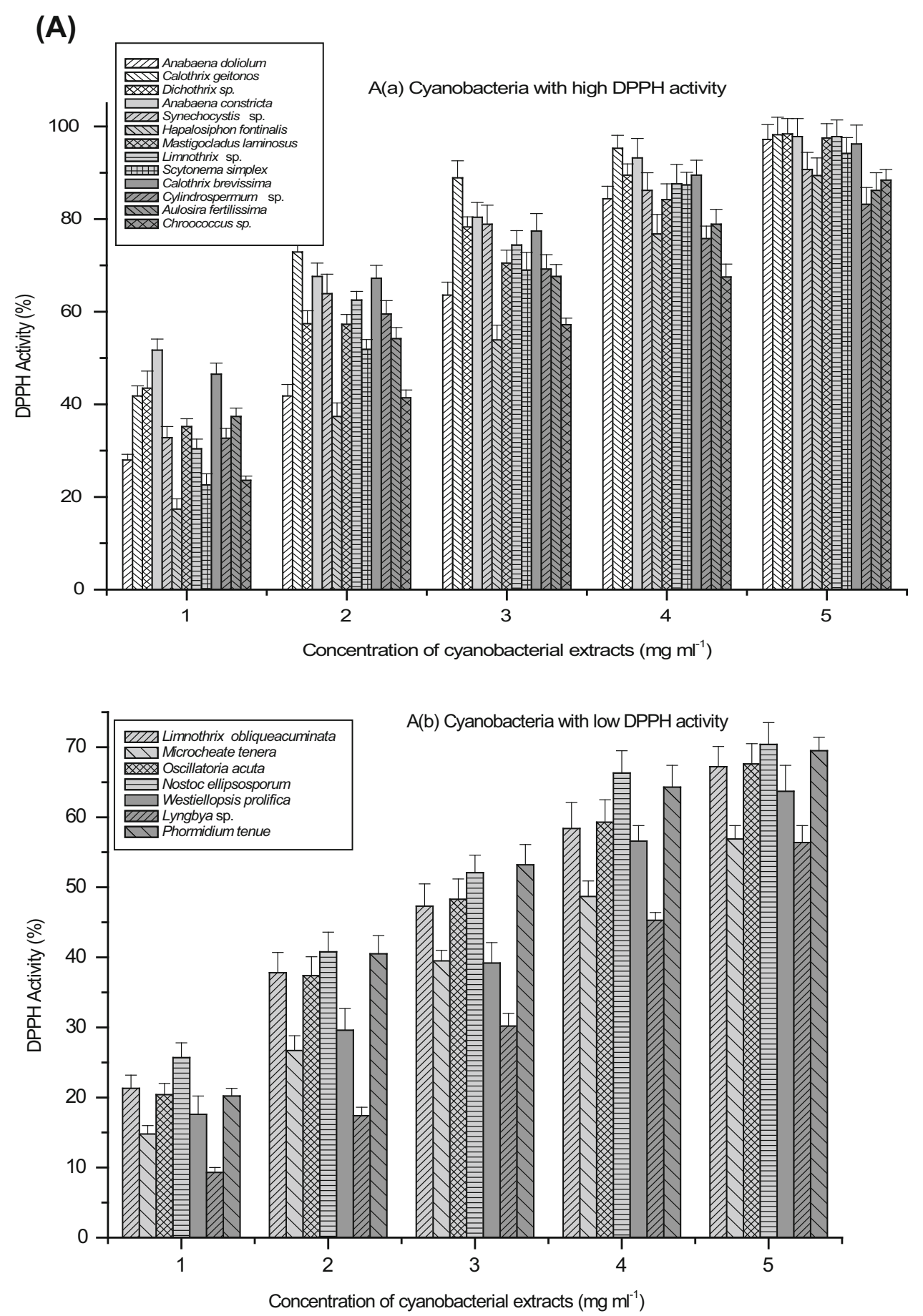

Specific biochemical fingerprints in terms of smallmolecule metabolites in real time can be obtained with the help of LC-MS/MS studies (Daviss 2005). Targeted metabolic profiling of cyanobacterial polyphenolic-rich extracts using HPLC has resulted in the characterization of five phenolic acids namely gallic, chlorogenic, caffeic, ferulic and vanillic acids and three flavonoids namely rutin, quercetin and kaempferol in various quantities (Table 3). Persistent presence of gallic acid was observed in all the strains and the maximum content was $99.03 \mu \mathrm{g} \mathrm{g}^{-1}$ fresh wt in $L$. obliqueacuminata followed by $83.7 \mu \mathrm{g} \mathrm{g}^{-1}$ fresh wt in $\mathrm{Di}$ chothrix sp. and $77.73 \mu \mathrm{g} \mathrm{g}^{-1}$ fresh wt in P. tenue (Table 3). Minimum content of gallic acid was as low as $16.47 \mu \mathrm{g} \mathrm{g}^{-1}$ fresh wt in N. ellisposporum. Among other phenolic acids, presence of chlorogenic acid was detected in various quantities in 13 strains, caffeic acid in 12 , ferulic acid in 10 , vanillic acid in 14, rutin in 16, quercetin in 15 and kaempferol in 15 strains. Chlorogenic acid content was maximum 
Fig. 2 continued
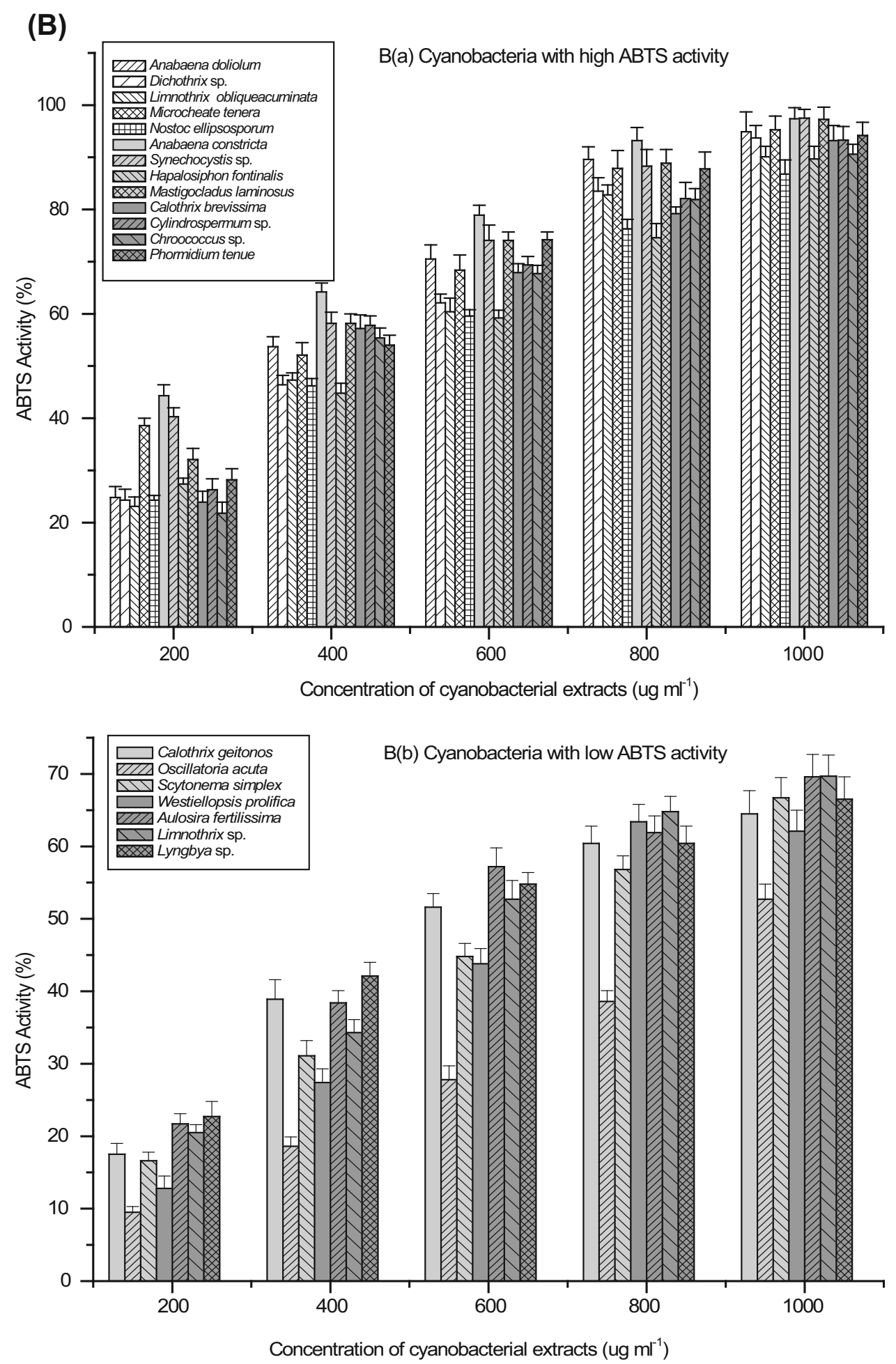

(77.9 $\mathrm{g} \mathrm{g} \mathrm{g}^{-1}$ fresh $\left.\mathrm{wt}\right)$ in $M$. tenera while minimum (1.9 $\mathrm{g} \mathrm{g} \mathrm{g}^{-1}$ fresh wt) in Lyngbya sp. Maximum content of caffeic acid (95.9 $\mathrm{Mg} \mathrm{g}^{-1}$ fresh wt) was found in A. fertilissima, ferulic acid (37.4 $\mu \mathrm{g} \mathrm{g}^{-1}$ fresh wt) in $O$ acuta, vanillic acid $\left(27.4 \mu \mathrm{g} \mathrm{g}^{-1}\right.$ fresh wt) in $M$. laminosus, rutin

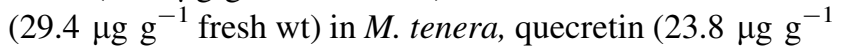

fresh wt) in $N$. ellipsosporum and kaempferol $\left(7.8 \mu \mathrm{g} \mathrm{g}^{-1}\right.$ fresh wt) in $M$. tenera (Table 3). These metabolites were further verified by LC-MS/MS studies using $[\mathrm{M}-\mathrm{H}]^{-}$ion for gallic $m / z$ 169, chlorogenic $\mathrm{m} / \mathrm{z} 353$, caffeic $m / z .179$, vanillic $\mathrm{m} / \mathrm{z} 167$ and ferulic acid $\mathrm{m} / \mathrm{z} 193$ and rutin $\mathrm{m} / \mathrm{z}$ 609, quercetin $\mathrm{m} / \mathrm{z} 301$ and kaempferol $\mathrm{m} / \mathrm{z}, 185$. 
Fig. 2 continued
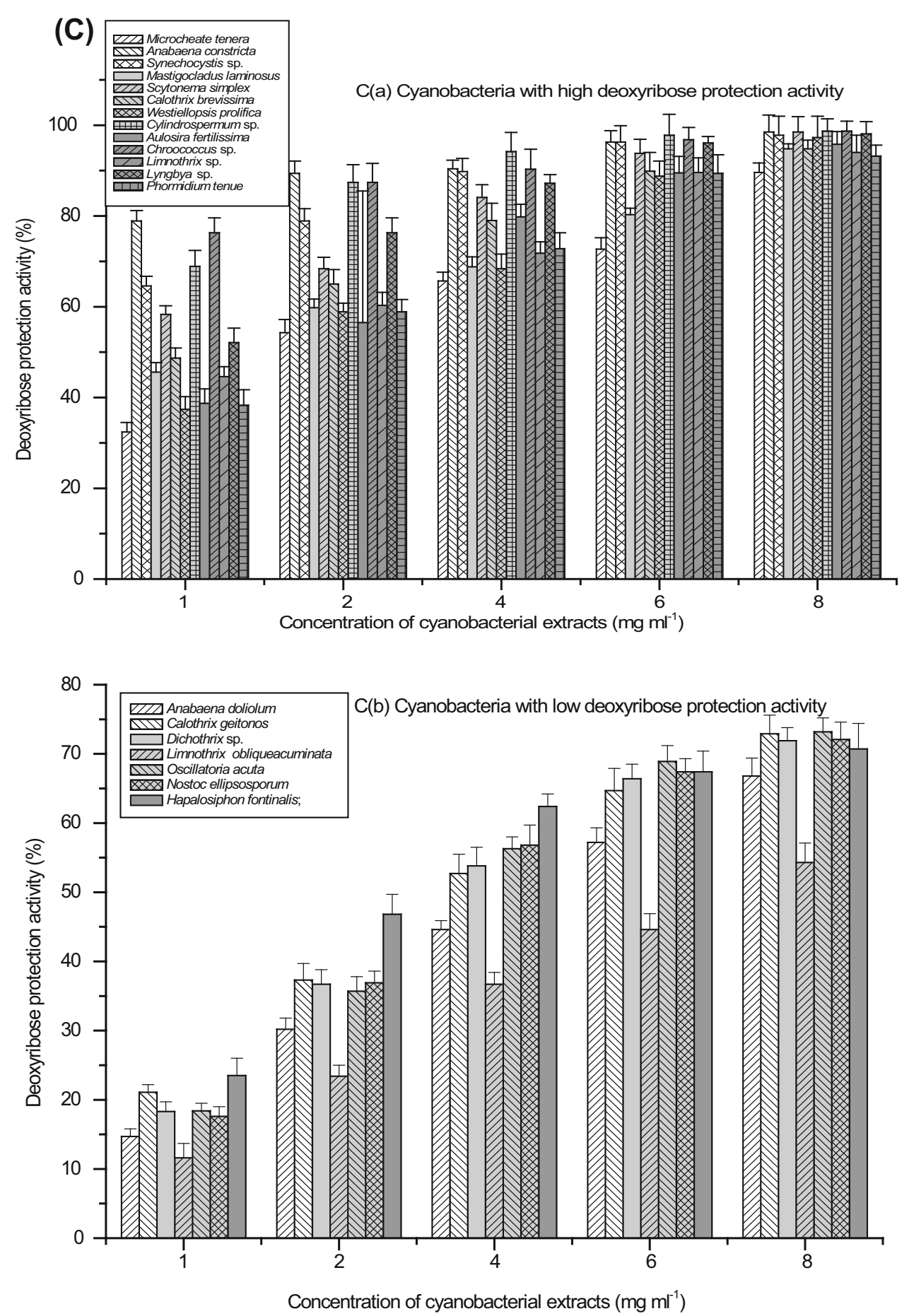

Prominent DPPH, ABTS and deoxyribose protection activity was observed in the polyphenolics compounds that were identified in different quantities in cyanobacterial extracts (Table 4). Gallic ( $\mathrm{IC}_{50} 3.53 \mu \mathrm{g} \mathrm{ml}^{-1}$ ), chlorogenic $\left(\mathrm{IC}_{50} 6.41 \mu \mathrm{g} \mathrm{ml}^{-1}\right)$, caffeic $\left(\mathrm{IC}_{50} 6.34 \mu \mathrm{g} \mathrm{ml}^{-1}\right.$ ) were found more prominent in DPPH activity along with other compounds (except vanillic acid) than the standard compounds BHT $\left(\mathrm{IC}_{50} 12.41 \mu \mathrm{g} \mathrm{ml}^{-1}\right.$ ) and $\alpha$-tocoferol $\left(\mathrm{IC}_{50}\right.$ $10.87 \mu \mathrm{g} \mathrm{ml}^{-1}$ ). Similarly, ABTS activity of kaempferol and gallic acid was $\left(\mathrm{IC}_{50} 8.54\right.$ and $8.85 \mu \mathrm{g} \mathrm{ml}^{-1}$, respectively) very prominent in comparison to BHT and $\alpha$-tocoferol and most of the compounds except vanillic acid 
Fig. 2 continued

(D)
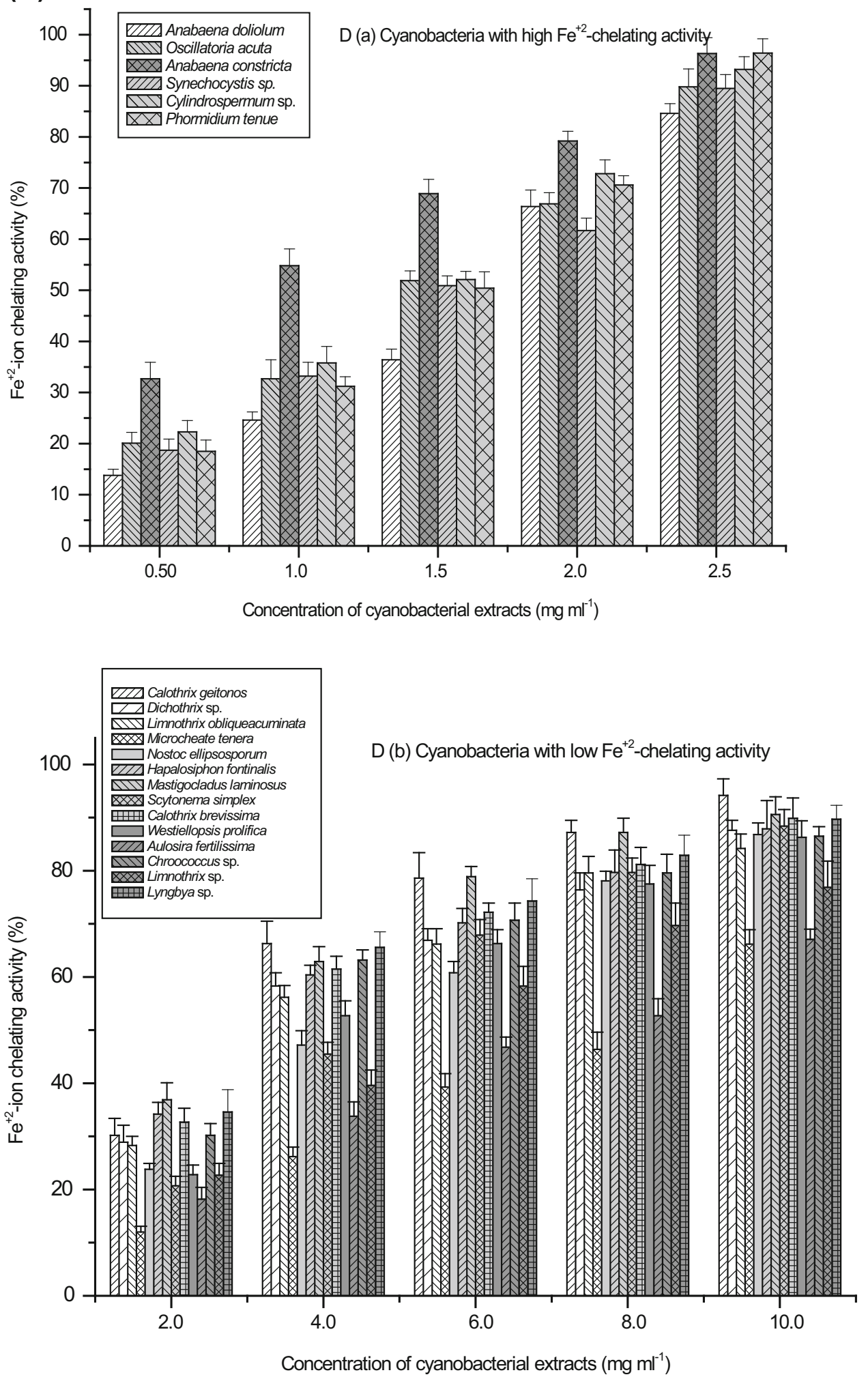

identified in the cyanobacterial extracts were even more prominent than $\alpha$-tocoferol in ABTS activity. Ferulic acid was found to be very effective in deoxyribose protection $\left(\mathrm{IC}_{50} 4.51 \mu \mathrm{g} \mathrm{ml}^{-1}\right.$ ) while other compounds also proven comparatively good in comparison to BHT and $\alpha$-tocoferol. Such results reflect a clear correlation in between the presence of different polyphenolics biomolecules in the cyanobacterial extracts and prominent antioxidant activity 
Table 3 Quantitative content of phenolic acids and flavonoids in cyanobacterial cell-free extracts

\begin{tabular}{|c|c|c|c|c|c|c|c|c|}
\hline \multirow[t]{2}{*}{ Cyanobacteria } & \multicolumn{5}{|c|}{ Phenolic acids $\left(\mu \mathrm{g} \mathrm{g}^{-1}\right.$ fresh wt) } & \multicolumn{3}{|c|}{ Flavonoids $\left(\mu \mathrm{g} \mathrm{g}^{-1}\right.$ fresh wt) } \\
\hline & $\begin{array}{l}\text { Gallic acid } \\
\left(2.73^{\mathrm{A}}\right)\end{array}$ & $\begin{array}{l}\text { Chlorogenic } \\
\text { acid }\left(3.04^{\mathrm{A}}\right)\end{array}$ & $\begin{array}{l}\text { Caffeic acid } \\
\left(3.58^{\mathrm{A}}\right)\end{array}$ & $\begin{array}{l}\text { Vanillic acid } \\
\left(3.89^{\mathrm{A}}\right)\end{array}$ & $\begin{array}{l}\text { Ferulic acid } \\
\left(4.76^{\mathrm{A}}\right)\end{array}$ & $\begin{array}{l}\text { Rutin } \\
\left(4.06^{\mathrm{A}}\right)\end{array}$ & $\begin{array}{l}\text { Quercetin } \\
\left(9.24^{\mathrm{A}}\right)\end{array}$ & $\begin{array}{l}\text { Kaempferol } \\
\left(15.5^{\mathrm{A}}\right)\end{array}$ \\
\hline Anabaena doliolum & $45.73^{\mathrm{g}}$ & $27.4 \pm 6.1^{\mathrm{de}}$ & $7.6 \pm 0.65^{\mathrm{de}}$ & $12.7 \pm 1.07^{\mathrm{c}}$ & $\mathrm{ND}^{\mathrm{k}}$ & $12.8 \pm 0.41^{\mathrm{b}}$ & $9.7 \pm 0.66^{\mathrm{e}}$ & $\mathrm{ND}^{\mathrm{j}}$ \\
\hline Calothrix geitonos & $34.40^{\mathrm{h}}$ & $\mathrm{ND}^{\mathrm{g}}$ & $\mathrm{ND}^{\mathrm{g}}$ & $3.8 \pm 0.3^{\mathrm{f}}$ & $1.7 \pm 0.09^{\mathrm{j}}$ & $12.0 \pm 0.4^{\mathrm{c}}$ & $8.9 \pm 0.5^{\mathrm{e}}$ & $3.0 \pm 0.4^{\mathrm{efg}}$ \\
\hline Dichothrix sp. & $83.70^{\mathrm{b}}$ & $72.0 \pm 8.3^{\mathrm{b}}$ & $\mathrm{ND}^{\mathrm{g}}$ & $2.0 \pm 0.31^{\mathrm{fgh}}$ & $3.7 \pm 0.25^{\mathrm{i}}$ & $2.5 \pm 0.4^{\mathrm{i}}$ & $7.5 \pm 0.4^{\mathrm{f}}$ & $3.6 \pm 0.56^{\text {cde }}$ \\
\hline $\begin{array}{l}\text { Limnothrix } \\
\quad \text { obliqueacuminata }\end{array}$ & $99.03^{\mathrm{a}}$ & $28.1 \pm 1.7^{\mathrm{de}}$ & $\mathrm{ND}^{\mathrm{g}}$ & $\mathrm{ND}^{\mathrm{h}}$ & $17.9 \pm 0.65^{\mathrm{c}}$ & $3.0 \pm 0.55^{\mathrm{hi}}$ & $12.4 \pm 0.43^{\mathrm{c}}$ & $1.9 \pm 0.45^{\mathrm{hi}}$ \\
\hline Microcheate tenera & $47.03^{\mathrm{g}}$ & $77.9 \pm 2.2^{\mathrm{a}}$ & $\mathrm{ND}^{\mathrm{g}}$ & $24.4 \pm 3.15^{\mathrm{b}}$ & $\mathrm{ND}^{\mathrm{k}}$ & $29.4 \pm 0.72^{\mathrm{a}}$ & $18.4 \pm 0.85^{\mathrm{b}}$ & $7.8 \pm 0.7^{\mathrm{a}}$ \\
\hline Oscillatoria acuta & $25.67^{\mathrm{ij}}$ & $\mathrm{ND}^{\mathrm{g}}$ & $25.3 \pm 4.03^{\mathrm{c}}$ & $7.6 \pm 0.32^{\mathrm{e}}$ & $37.4 \pm 1.2^{\mathrm{a}}$ & $3.4 \pm 0.37^{\text {gh }}$ & $\mathrm{ND}^{\mathrm{h}}$ & $1.8 \pm 0.4^{\mathrm{hi}}$ \\
\hline Nostoc ellipsosporum & $16.47^{\mathrm{k}}$ & $4.2 \pm 0.22^{\mathrm{fg}}$ & $8.2 \pm 0.45^{\mathrm{de}}$ & $1.4 \pm 0.15^{\mathrm{gh}}$ & $8.9 \pm 0.43^{\mathrm{e}}$ & $\mathrm{ND}^{\mathrm{k}}$ & $23.8 \pm 1.03^{\mathrm{a}}$ & $4.3 \pm 0.6^{\mathrm{bc}}$ \\
\hline Anabaena constricta & $22.60^{\mathrm{j}}$ & $\mathrm{ND}^{\mathrm{g}}$ & $5.6 \pm 0.5^{\mathrm{ef}}$ & $1.2 \pm 0.36^{\mathrm{gh}}$ & $4.9 \pm 0.35^{\mathrm{h}}$ & $1.5 \pm 0.35^{\mathrm{j}}$ & $\mathrm{ND}^{\mathrm{h}}$ & $\mathrm{ND}^{\mathrm{j}}$ \\
\hline Synechocystis sp. & $24.53^{\mathrm{ij}}$ & $8.2 \pm .45^{\mathrm{f}}$ & $\mathrm{ND}^{\mathrm{g}}$ & $\mathrm{ND}^{\mathrm{h}}$ & $\mathrm{ND}^{\mathrm{k}}$ & $8.8 \pm 0.62^{\mathrm{d}}$ & $6.7 \pm 0.45^{\mathrm{f}}$ & $\mathrm{ND}^{\mathrm{j}}$ \\
\hline Hapalosiphon fontinalis & $35.63^{\mathrm{h}}$ & $41.2 \pm 4.2^{\mathrm{c}}$ & $45.1 \pm 1.98^{\mathrm{b}}$ & $\mathrm{ND}^{\mathrm{h}}$ & $16.96 \pm 1.06^{\mathrm{d}}$ & $3.7 \pm 0.45^{\mathrm{gh}}$ & $11.7 \pm 0.66^{\mathrm{cd}}$ & $4.8 \pm 0.6^{\mathrm{b}}$ \\
\hline Mastigocladus laminosus & $25.93^{\mathrm{ij}}$ & $\mathrm{ND}^{\mathrm{g}}$ & $8.8 \pm 0.7^{\mathrm{d}}$ & $27.4 \pm 3.15^{\mathrm{a}}$ & $\mathrm{ND}^{\mathrm{k}}$ & $13.4 \pm 0.46^{\mathrm{b}}$ & $\mathrm{ND}^{\mathrm{h}}$ & $\mathrm{ND}^{\mathrm{j}}$ \\
\hline Scytonema simplex & $27.60^{\mathrm{i}}$ & $\mathrm{ND}^{\mathrm{g}}$ & $5.5 \pm 0.65^{\mathrm{ef}}$ & $2.6 \pm 0.5^{\mathrm{fg}}$ & $5.8 \pm 0.65^{\mathrm{g}}$ & $3.9 \pm 0.8^{\mathrm{fg}}$ & $11.4 \pm 0.65^{\mathrm{d}}$ & $2.8 \pm 0.31^{\mathrm{fg}}$ \\
\hline Calothrix brevissima & $62.03^{\mathrm{e}}$ & $31.8 \pm 2.7^{\mathrm{d}}$ & $\mathrm{ND}^{\mathrm{g}}$ & $\mathrm{ND}^{\mathrm{h}}$ & $\mathrm{ND}^{\mathrm{k}}$ & $4.6 \pm 0.56^{\mathrm{ef}}$ & $11.2 \pm 0.62^{\mathrm{d}}$ & $\mathrm{ND}^{\mathrm{j}}$ \\
\hline Westiellopsis prolifica & $43.13^{\mathrm{g}}$ & $9.3 \pm 0.4^{\mathrm{f}}$ & $3.7 \pm 0.5^{\mathrm{f}}$ & $2.8 \pm 0.25^{\mathrm{fg}}$ & $\mathrm{ND}^{\mathrm{k}}$ & $\mathrm{ND}^{\mathrm{k}}$ & $3.7 \pm 0.55^{\mathrm{g}}$ & $7.8 \pm 0.46^{\mathrm{a}}$ \\
\hline Cylindrospermum sp. & $36.97^{\mathrm{h}}$ & $\mathrm{ND}^{\mathrm{g}}$ & $6.6 \pm 0.64^{\mathrm{de}}$ & $2.7 \pm 0.4^{\mathrm{fg}}$ & $\mathrm{ND}^{\mathrm{k}}$ & $\mathrm{ND}^{\mathrm{k}}$ & $8.9 \pm 0.8^{\mathrm{e}}$ & $3.9 \pm 0.36^{\mathrm{cd}}$ \\
\hline Aulosira fertilissima & $24.80^{\mathrm{ij}}$ & $\mathrm{ND}^{\mathrm{g}}$ & $95.9 \pm 4.94^{\mathrm{a}}$ & $\mathrm{ND}^{\mathrm{h}}$ & $\mathrm{ND}^{\mathrm{k}}$ & $\mathrm{ND}^{\mathrm{k}}$ & $4.3 \pm 0.55^{\mathrm{g}}$ & $3.3 \pm 0.56^{\mathrm{def}}$ \\
\hline Chroococcus sp. & $67.97^{\mathrm{d}}$ & $37.8 \pm 2.9^{\mathrm{c}}$ & $\mathrm{ND}^{\mathrm{g}}$ & $10.5 \pm 0.97^{\mathrm{d}}$ & $7.8 \pm 0.7^{f}$ & $1.4 \pm 0.35^{\mathrm{j}}$ & $\mathrm{ND}^{\mathrm{h}}$ & $3.0 \pm 0.4^{\mathrm{efg}}$ \\
\hline Limnothrix sp. & $55.23^{\mathrm{f}}$ & $27.1 \pm 3.3^{\mathrm{de}}$ & $\mathrm{ND}^{\mathrm{g}}$ & $3.8 \pm 0.65^{\mathrm{f}}$ & $\mathrm{ND}^{\mathrm{k}}$ & $8.6 \pm 0.57^{\mathrm{d}}$ & $11.3 \pm 0.7^{\mathrm{d}}$ & $2.7 \pm 0.47^{\mathrm{fg}}$ \\
\hline Lyngbya sp. & $35.43^{\mathrm{h}}$ & $1.9 \pm 0.2^{\mathrm{g}}$ & $3.7 \pm 0.55^{\mathrm{f}}$ & $2.8 \pm 0.7^{\mathrm{fg}}$ & $\mathrm{ND}^{\mathrm{k}}$ & $8.8 \pm 0.6^{\mathrm{d}}$ & $\mathrm{ND}^{\mathrm{h}}$ & $2.5 \pm 0.4^{\mathrm{gh}}$ \\
\hline Phormidium tenие & $77.73^{c}$ & $23.5 \pm 3.8^{\mathrm{e}}$ & $5.5 \pm 0.51^{\mathrm{ef}}$ & $\mathrm{ND}^{\mathrm{h}}$ & $27.3 \pm 1.12^{\mathrm{b}}$ & $5.2 \pm 0.46^{\mathrm{e}}$ & $11.3 \pm 0.56^{\mathrm{d}}$ & $1.6 \pm 0.25^{\mathrm{i}}$ \\
\hline $\mathrm{SEM} \pm$ & 1.51 & 1.70 & 0.89 & 0.63 & 0.30 & 0.28 & 0.32 & 0.24 \\
\hline $\mathrm{CD}(p<0.05)$ & 4.32 & 4.86 & 2.55 & 1.80 & 0.87 & 0.79 & 0.92 & 0.68 \\
\hline $\mathrm{CV}(\%)$ & 5.90 & 15.10 & 14.00 & 20.70 & 8.00 & 7.80 & 6.90 & 15.00 \\
\hline
\end{tabular}

Retention time in min; ND- not detectable; Values represent average \pm standard deviation for three replications; values in the same column with different superscripts are significantly different at $p<0.05$

Table 4 Antioxidant activity of phenolics acids and flavonoids identified in the cyanobacterial extracts

\begin{tabular}{lccc}
\hline Polyphenolics & \multicolumn{3}{l}{ Antioxidant activity } \\
\cline { 2 - 4 } & DPPH activity $\left(\mathrm{IC}_{50}\right)\left(\mu \mathrm{g} \mathrm{ml}^{-1}\right)$ & $\mathrm{ABTS}$ activity $\left(\mathrm{IC}_{50}\right)\left(\mu \mathrm{g} \mathrm{ml}^{-1}\right)$ & Deoxyribose protection activity $\left(\mathrm{IC}_{50}\right)\left(\mu \mathrm{g} \mathrm{ml}{ }^{-1}\right)$ \\
\hline Gallic acid & $3.53 \pm 0.24$ & $8.85 \pm 0.74$ & $7.84 \pm 0.72$ \\
Chlorogenic acid & $6.41 \pm 0.61$ & $13.15 \pm 0.71$ & $8.53 \pm 0.62$ \\
Caeffic acid & $6.34 \pm 0.37$ & $18.04 \pm 0.68$ & $4.76 \pm 0.67$ \\
Vanillic acid & $416.7 \pm 6.2$ & $132.1 \pm 3.4$ & $91.1 \pm 5.2$ \\
Ferulic acid & $11.75 \pm 0.75$ & $9.47 \pm 0.69$ & $4.51 \pm 0.37$ \\
Rutin & $6.55 \pm 0.54$ & $13.78 \pm 0.93$ & $7.58 \pm 0.66$ \\
Quercetin & $4.71 \pm 0.49$ & $10.63 \pm 0.83$ & $20.1 \pm 0.84$ \\
Kaempferol & $17.30 \pm 1.3$ & $8.54 \pm 0.6$ & $7.17 \pm 0.46$ \\
BHT & $12.41 \pm 1.6$ & $16.12 \pm 1.3$ & $6.1 \pm 0.45$ \\
$\alpha$-Tocoferol & $10.87 \pm 1.2$ & $32.41 \pm 1.7$ & $8.37 \pm 0.72$ \\
\hline
\end{tabular}

Values represent average \pm standard deviation for three replications 
shown by the extracts. This is probably a direct evidence to support the assumption that polyphenolics in cyanobacterial extracts are responsible for the antioxidant properties offered by the organisms. Phytochemicals of natural origin are becoming a prominent source of antioxidant molecules. Cyanobacteria could be one of the most potential source for the production of natural antioxidants. Phenolic acids and flavonoids from plant sources have been well-documented for their antioxidant, free-radical quenching and redox metal ion-chelating affects (Singh et al. 2009, 2014; Tutour 1990; Apati et al. 2003; Hossain et al. 2016) but cyanobacteria and microalgae are relatively new source for such compounds in recent years due to their potential benefits and ease of production (Guedes et al. 2013; Machu et al. 2015). Gallic, chlorogenic, caffeic and ferulic acids identified from plant sources have been known as strong antioxidants and free radical scavengers (Piazzon et al. 2012; Babić et al. 2015) but their presence in cyanobacteria is scarcely reported and this make these organisms more potential. Being most primitive, these organisms are considered to evolve with various levels of environmental adaptations to overcome these stresses for their survival over the time (Tandeau-de-Marsac and Houmard 1993). This study implicates that the antioxidant properties of the cyanobacterial extracts can be thought of a reflection of intrinsic strategies of these organisms to reduce the damage caused due to ROS generated during environmental stresses. The presence of polyphenolics (phenolic acids and flavonoids) and high PAL activity in cyanobacteria may also be considered as a part of the key functions responsible for the protection of these organisms from environmental stresses during the course of their evolution (Aydas et al. 2013; Singh et al. 2014). This further may add functional values such as free-radical quenching, metal chelation and ROS-scavenging activity to the properties of these organisms.

\section{Conclusion}

Despite of possessing unique secondary metabolites with potential biological activities, cyanobacteria are a nonconventional and less worked-out source of phenylpropanoids. Evaluation of cell-free extracts of twenty cyanobacterial strains from different genera i.e., Anabaena, Nostoc, Microcheate, Oscillatoria, Synechocystis, Hapalosiphon, Mastigocladus, Scytonema, Westiellopsis, Cylindrospermum, Aulosira, Chroococcus, Lyngbya, Calothrix, Dichothrix, Limnothrix and Phormidium indicated prominent biological potential based on DPPH, ABTS, deoxyribose protection and $\mathrm{Fe}^{+2}$ ion chelating activities. Presence of significant amount of PAL activity, total phenolics and flavonoids and phenylpropanoid metabolites is linked with the indicated biological effects. A direct correlation between phenylpropanoids in the extracts and the antioxidant properties was found indicating that the polyphenolics in the cyanobacterial extracts may be accountable for their antioxidant properties. Presence of phenylpropanoids gallic, chlorogenic, caffeic, vanillic and ferulic acids and flavonoids rutin, quercetin and kaempferol in cyanobacterial extracts and their correlation with antioxidant properties make these organisms potentially viable source of biomolecules. In addition, dominant presence of polyphenols as antioxidants in cyanobacterial species may be presumed as the adaptation strategies of these organisms against abiotic stresses due to their specific habitats.

Acknowledgements The work was carried out under the Institute project of ICAR-NBAIM, India undertaken by DPS.

\section{Compliance with ethical standards}

Conflict of interest Authors declared no conflict of interest.

\section{References}

Apati P, Szentmihalyi K, KristoSz T, Papp I, Vinkler P, Szoke E, Kery A (2003) Herbal remedies of Solidago, correlation of phytochemical characteristics and antioxidative properties. J Pharm Biomed Anal 32:1045-1053

Aydas SB, Ozturk S, Aslim B (2013) Phenylalanine ammonia lyase (PAL) enzyme activity and antioxidant properties of some cyanobacteria isolates. Food Chem 136:164-169

Babić O, Kovač D, Rašeta M, Šibul F, Svirčev Z, Simeunović J (2015) Evaluation of antioxidant activity and phenolic profile of filamentous terrestrial cyanobacterial strains isolated from forest ecosystem. J Appl Phycol 28:2333-2342

Bharanidharan M, Sivasubramanian V, Raja SR, Nayagam V (2013) Evaluation of antioxidant and antimicrobial potential of cyanobacteria, Chroococcus turgidus (Kützing) Nägeli. Int J Curr Microbiol App Sci 2:300-305

Bondet V, Brand-Williams W, Berset C (1997) Kinetics and mechanisms of antioxidant activity using the DPPH.free radical method. Lebensm Wiss Technol 30:609-615

Camacho FA (2008) Macroalgal and cyanobacterial chemical defenses in freshwater communities. In: Amsler FA (ed) Algal chemical ecology. Springer-Verlag, Berlin, pp 105-109

Chumark P, Khunawat P, Sanvarinda Y, Phornchirasilp S, Morales NP, Phivthong-Ngam L, Ratanachamnong P, Srisawat S, Pongrapeeporn KU (2008) The in vitro and ex vivo antioxidant properties, hypolipidaemic and antiatherosclerotic activities of water extract of Moringa oleifera Lam leaves. J Ethnopharmacol 116:439-446

Daviss B (2005) Growing pains for metabolomics. The Scientist 19:25-28

Dinis TCP, Madeira VMC, Almeida MLM (1994) Action of phenolic derivates (acetoaminophen, salycilate and 5-aminosalycilate) as inhibitors of membrane lipid peroxidation and as peroxyl radical scavengers. Arch Biochem Biophys 315:161-169

Ferjani A, Mustardy L, Sulpice R, Marin K, Suzuki I, Hagemann M, Murata N (2003) Glucosylglycerol, a compatible solute, sustains cell division under salt stress. Plant Physiol 131:1628-1637 
Fraga CG, Galleano M, Verstraeten SV, Oteiza PI (2010) Basic biochemical mechanisms behind the health benefits of polyphenols. Mol Aspects Med 31:435-445

Giao MS, Gonzalez-Sanjose ML, Perez MDR, Pereira CI, Pintado ME, Malcata FX (2007) Infusion of Portuguese medicinal plants: dependence of final antioxidant capacity and phenolic content on extraction features. J Sci Food Agri 87:2638-2647

Guedes AC, Gião MS, Seabra R, Ferreira AC, Tamagnini P, MoradasFerreira P, Malcata FX (2013) Evaluation of the antioxidant activity of cell extracts from microalgae. Mar Drugs 11:1256-1270

Gutteridge JMC (1984) Reactivity of hydroxyl and hydroxyl-like radicals discriminated by release of thiobarbituric acid-reactive material from deoxysugars, nucleotides and benzoate. J Biochem 224:761-767

Halliwell B, Gutteridge JM (1984) Oxygen toxicity, oxygen radicals, transition metals and disease. Biochem J 219:1-14

Hanson KR, Havir EA (1981) Phenylalanine ammonia-lyase. In: Stumpf PK, Conn EE (eds) The biochemistry of plants. Academic Press, New York, pp 577-625

Hossain MF, Ratnayake RR, Meerajini K, Kumara KLW (2016) Antioxidant properties in some selected cyanobacteria isolated from fresh water bodies of Sri Lanka. Food Sci Nutr. doi:10. $1002 / \mathrm{fsn} 3.340$

Kim DO, Chun OK, Kim YJ, Moon HY, Lee CY (2003) Quantification of polyphenolics and their antioxidant capacity in fresh plums. J Agric Food Chem 51:6509-6515

Lowry OH, Rosebrough NJ, Farr AL, Randall RJ (1951) Protein measurement with the Folin phenol reagent. J Biol Chem 193:265-275

Machu L, Misurcova L, Ambrozova JV, Orsavova J, Mlcek J, Sochor J, Jurikova T (2015) Phenolic acids and antioxidants in algal food products. Molecules 20:1118-1133

Mandal S, Rath J (2015) Secondary metabolites of cyanobacteria and drug development. In: Mandal S, Rath J (eds) Extremophilic cyanobacteria for novel drug development. Springer, Switzerland, pp 23-43

McCallum JA, Walker JRL (1990) Phenolic biosynthesis during grain development in wheat: changes in phenylalanine ammonia-lyase activity and soluble phenolic content. J Cereal Sci 11:35-49

Nordberg J, Arnér ES (2001) Reactive oxygen species, antioxidants, and the mammalian thioredoxin system. Free Radic Biol Med 31:1287-1312

Perron NR, Brumaghim JL (2009) A review of the antioxidant mechanisms of polyphenol compounds related to iron binding. Cell Biochem Biophys 53:75-100

Piazzon A, Vrhovsek U, Masuero D, Mattivi F, Mandoj F, Nardini M (2012) Antioxidant activity of phenolic acids and their metabolites: synthesis and antioxidant properties of the sulfate derivatives of ferulic and caffeic acids and of the acyl glucuronide of ferulic acid. J Agri Food Chem 60:12312-12323

Rastogi RP, Sinha RP (2009a) Biotechnological and industrial significance of cyanobacterial secondary metabolites. Biotechnol Adv 27:521-539
Rastogi RP, Sinha RP (2009b) Biotechnological and industrial significance of cyanobacterial secondary metabolites. Biotechnol Adv 27(4):521-539

Reuter S, Gupta SC, Chaturvedi MM, Aggarwal BB (2010) Oxidative stress, inflammation and cancer: how are they linked? Free Radical Bio Med 49:1603-1616

Ronald P, Soderhall K (1985) Phenylalanine ammonia lyase and peroxidase activity in mycorrhizal and nonmycorrhizal short roots of scots pine, Pinus sylvestris L. New Phytol 101:487-494

Shalaby EA, Shanab SMM (2013) Comparison of DPPH and ABTS assays for determining antioxidant potential of water and methanolic extracts of Spirulina platensis. Ind J Geo-Mar Sci 42:556-564

Singh DP, Tyagi MB, Kumar A, Thakur JK, Kumar A (2001) Antialgal activity of a hepatotoxin-producing cyanobacterium, Microcystis aeruginosa. World J Microbiol Biotechnol 17:15-22

Singh BN, Singh BR, Singh RL, Prakash D, Singh DP, Sarma BK, Upadhyay G, Singh HB (2009) Polyphenolics from various extracts/fraction of red onion (Allium cepa) peel with potential antioxidant and antimutagenic activities. Food Chem Toxicol 47:1161-1167

Singh DP, Prabha R, Yandigeri MS, Arora DK (2011) Cyanobacteriamediated phenylpropanoids and phytohormones in rice (Oryza sativa) enhance plant growth and stress tolerance. Antonie Van Leeuwenhoek 100:557-568

Singh DP, Prabha R, Meena KK, Sharma L, Sharma AK (2014) Induced accumulation of polyphenolics and flavonoids in cyanobacteria under salt stress protects organisms through enhanced antioxidant activity. American J Plant Sciences 5:726-735

Stanier RY, Kunisawa R, Mandel M, Cohen-Bazire G (1971) Purification and properties of unicellular blue-green algae (order-Chroococcales). Bacteriol Rev 35:171-305

Tandeau-de-Marsac N, Houmard J (1993) Adaptation of cyanobacteria to environmental stimuli: new steps towards molecular mechanisms. FEMS Microbiol Rev 104:119-190

Tomitani A, Knoll AH, Cavanaugh CM, Ohno T (2006) The evolutionary diversification of cyanobacteria: molecular-phylogenetic and paleontological perspectives. Proc Natl Acad Sci USA 103:5442-5447

Tutour BL (1990) Antioxidative activities of algal extracts, synergistic effect with vitamin E. Phytochem 29:3759-3765

Vogt T (2010) Phenylpropanoid biosynthesis. Mol Plant 3:2-20

Wojdylo A, Oszmianski J, Czemerys R (2007) Antioxidant activity and phenolic compounds in 32 selected herbs. Food Chem 105:940-949

Xue Y, He Q (2015) Cyanobacteria as cell factories to produce plant secondary metabolites. Front Bioeng Biotechnol 3:57

Yasuda T, Inaba A, Ohmori M, Endo T, Kubo S, Ohsawa K (2000) Urinary metabolites of gallic acid in rats and their radical scavenging effect on DPPH. J Nat Prod 63:1444-1446

Yen GC, Duh PD (1994) Scavenging effect of methanolic extracts of peanut hulls on free radical and anti oxygen. Agric Food Chem $42: 629-632$ 